\title{
THE RESILIENCE OF THE HUMAN RIGHTS NORM IN AN ERA OF COUNTER-TERRORISM
}

\author{
Salma Yusuf ${ }^{1}$ \\ University of Colombo
}

\begin{abstract}
:
This article seeks to explore the tensions arising from the interaction between human rights and counter-terrorism and contribute to the debate on the feasibility of sustaining the former in such trying situations as the latter through the determination of a role for the United Nations' Human Rights treaty monitoring bodies in protecting human rights while countering terrorism. While the article acknowledges and does not for a moment suggest that this mechanism is intended to be the panacea for the problem raised, it is explored with the understanding of its potential in contributing to the work of the larger United Nations' human rights machinery in protecting human rights while countering terrorism. The article begins with a brief discussion of the relationship between counter-terrorism and human rights and the many controversies surrounding the debate which will be the focus of the first part of the article. The second part provides a detailed examination and thematic analysis of the work of the United Nations' human rights treaty bodies in the area of protecting human rights while countering terrorism through which a role for the human rights treaty monitoring bodies is seen to emerge. This role is given further perspective and refinement through the addressing of the weaknesses, both internal and external, of the United Nations' human rights treaty system and through recommendations for further action which will be the focus of the third part of the article.
\end{abstract}

Keywords: Human Rights, Counter-terrorism, United Nations.

\section{Resumen:}

Este artículo tiene como objetivo analizar las tensiones derivadas de la interacción entre los Derechos Humanos y el contraterrorismo. Se contribuye de esta manera al debate sobre la posibilidad de mantener tales derechos en las complejas circunstancias derivadas de la ejecución de politicas de contra-terrorismo, definiendo un papel para los organismos de las Naciones Unidas encargados de velar por el cumplimiento de los Derechos Humanos. Este artículo ni mucho menos pretende que los mecanismos en discusión representen la panacea para el problema planteado, si bien se consideran entendiendo su potencial para contribuir a su mejor utilización por parte de los organismos de las Naciones Humanas aun cuando se den circunstancias en las que los imperativos del contraterrorismo puedan resultar en un desafio a su cumplimiento. El artículo empieza con una breve discusión sobre entre contraterrorismo y Derechos Humanos y las muchas controversias que rodean al debate, tema al que se dedica por entero la primera parte. La segunda parte proporciona un detallado examen y análisis temático de la labor de las organismos que velan por los Derechos Humanos en el seno de las Naciones Unidas para los que deriva un papel de protección cuando se apliquen políticas de contraterrorismo. A este papel se le otorga una perspectiva más definida a través del estudio de las debilidades, tanto internas como externas, del sistema de Derechos Humanos de las Naciones Unidas y a través de una serie de recomendaciones para su mejora y de las que tratará la tercera parte.

Palabras clave: Derechos Humanos, Contraterrorismo, Naciones Unidas.

Copyright (C) UNISCI, 2012.

Las opiniones expresadas en estos artículos son propias de sus autores, y no reflejan necesariamente la opinion de UNISCI. The views expressed in these articles are those of the authors, and do not necessarily reflect the views of UNISCI.

\footnotetext{
${ }^{1}$ Salma Yusuf has a Master of Laws with a specialization in Public International Law from Queen Mary University of London and a Bachelor of Laws with Honours from University of London. She is Lecturer at University of Colombo; and at University of Northumbria - Regional Campus for Sri Lanka \& Maldives. She currently serves in the fields of Public International Law and Human Rights, Social Justice, Transitional Justice, Peace-building and Reconciliation in Post-War Societies at both national and international organizations including the German International Cooperation and the Asia Foundation. She has previously served at the United Nations Development Programme and the Canadian International Development Agency. She provides expertise in legal analysis, policy development, advocacy, research and publishing. Email:
} salma.yusuf@alumni.qmul.net. 


\section{Introduction}

The twenty first century has brought with it a myriad of new questions for the subject of human rights. These 'new questions' can be considered as 'challenges' to the human rights discourse ${ }^{2}$ begging attention and serious consideration.

Among the many questions are 'Can Human Rights Survive?'3 raised by Conor Gearty; 'The question after September 11 is whether the era of human rights has come and gone,4 pondered by Michael Ignatieff and 'How resilient is the human rights norm in the counterterrorist era?' 5 posed by Rosemary foot.

A great many of these questions have been the result of an appreciation of the impact of the terrorist events of September 11 2001. There has been overwhelming unanimity and agreement among scholars, writers and practitioners that while terrorism is by no means a new phenomenon the events of September 11 signaled the birth of a 'new brand of terrorism.'

Jayantha Dhanapala explains that 'The terrorist attacks in the US on 11 September 2001 by their unexpected boldness, their diabolically elaborate intercontinental planning and the tragic scale of the death and destruction they wrought, are now widely regarded as a watershed in the global history of terrorism and political violence. This does not minimize the impact of terrorism in countries prior to $9 / 11 \ldots . .$. It is however a realistic assessment of the repercussions of a terrorist attack on the nerve centers of the sole superpower in the world and the global reaction to it. Nothing after $9 / 11$ will be as it was before. ${ }^{6}$

This 'new brand of terrorism, has consequently given rise to a "new brand of counterterrorism' measures.

Having said this, it should be stated that neither 'terrorism' nor 'human rights' are new phenomena. What is equally important to recognize, however, is that the attacks of September 11 has in fact created new challenges, new threats and hence new questions for the human rights movement. ${ }^{9}$

This article thus seeks to explore the question of the ability of sustaining human rights in the new and challenging context of counter terrorism. ${ }^{109}$ It seeks to do so by specifically

\footnotetext{
${ }^{2}$ Krasno, Jean E. (ed.) (2004): The United Nations: Confronting the Challenges of a Global Society, Boulder, Colo., Lynne Rienner Publishers: see section on "Twenty First Century Human Rights Challenges".

${ }^{3}$ Gearty, Conor (2006): Can Human Rights Survive? a symposium on the 2005 Hamlyn lectures, Cambridge, Cambridge University Press.

"Ignatieff, Michael: “Is the Human Rights Era Ending?”, New York Times, 5 February 2002.

5 Foot, Rosemary: "The United Nations, Counter Terrorism, and Human Rights: Institutional Adaptation and Embedded Ideas", Human Rights Quarterly vol. 29, no. 2 (2007), pp. 489-514.

${ }^{6}$ Dhanapala, Jayantha: “The United Nations' Response to 9/11” in Ranstorp, Magnus and Wilkinson, Paul (eds) (2008): Terrorism and Human Rights, London; New York, Routledge.

${ }^{7}$ Duner, Bertil: "Disregard for Security: The Human Rights movement and 9/11" in Ibid.

${ }^{8}$ Ibid.

9 Gaur, Mahendra (2003): Terrorism and Human Rights, New Delhi, Anamika Publications: "The post September $11 \ldots$ scenario is gradually unfolding itself in all its ramifications... The questions of human rights in the face of continuing terrorism has emerged as a major issue worldwide... The problem become more complex in the case of excesses and curtailment of fundamental rights and liberties of ordinary citizens in counter terrorism action".

${ }^{10}$ Inspired by the question raised by Rosemary Foot: "How resilient is the human rights norm in the counterterrorist era?" in Foot, op.cit., p 2.
} 
engaging in a determination of a role for the United Nations' human rights treaty monitoring bodies in its struggle for safeguarding human rights while countering terrorism.

As much of scholarly thinking and writing in this area has thus far been on the Counter Terrorism Committee, the work of the Secretary General, the Security Council and the General Assembly, this article seeks to probe the role of a less explored mechanism of the United Nations and one which it argues can gain increased currency for its potential to make a contribution to the work of the United Nations in this area, namely the human rights treaty monitoring bodies of the United Nations

The article employs a thematic approach by examining the work of the human rights treaty monitoring bodies in some of the specific aspects and specific rights which have been among the more contentions in the fight against terrorism. This list is not meant to be either comprehensive or exhaustive.

While the article acknowledges and does not for a moment suggest that this mechanism is intended to be the panacea for the problem raised, it is explored with the understanding of its potential in contributing to the work of the larger United Nations human rights machinery in its aim of protecting human rights while countering terrorism.

Further, as there have been warning signs of the appearance of the first signs of the 'marginalization of human rights treaty bodies as effective monitors of counter-terrorist policies, ${ }^{11}$ it is prudent to take a moment to increase focused study on this mechanism and uncover its potential role in this subject.

Moreover, this article draws inspiration from the Report of the Policy Working Group on the United Nations and Terrorism ${ }^{12}$ which was set up to draw attention to the far-reaching impacts of terrorism for the United Nations and propose courses of action to meet such challenges. Accordingly, this article seeks to contribute to the body of knowledge and understanding that might eventually lead to the achievement of this aim.

Taking a moment to step back and view the broader discussion it needs to be pointed out that the underlying acknowledgment in this article is that the United Nations cannot and should not be perceived as being obligated with the sole responsibility of undertaking the task of protecting human rights while countering terrorism since a multitude of other actors and actions are necessary to strengthen, reinforce and build on the work of the United Nations. ${ }^{13}$

Therefore, what the article seeks to expound is the role that the United Nations might play through its human rights treaty monitoring bodies within this larger framework.

\footnotetext{
11 Fitzpatrick, Joan: "Speaking Law to Power: The war Against Terrorism and Human Rights", European Journal of International Law, vol 14, no. 2 (2003), pp. 241-264.

12 Report of the Policy Working Group on the United Nations and Terrorism (United Nations) A/57/273 $5 / 2002 / 875$.

13 Joyner, Christopher: "The United Nations and Terrorism: Rethinking Legal Tensions Between National Security, Human Rights and Civil Liberties”, International Studies Perspectives, vol.5, no. 3 (2004), pp. 240257.
} 


\section{Counter-Terrorism and Human Rights: The Essential Relationship}

The existence of a relationship between counter terrorism and human rights is rarely, if ever, disputed. ${ }^{14}$ Hence, '[t]here seems to be widespread agreement on both the direct and indirect link between terrorism and human rights. ${ }^{15}$ What has been the subject of much contention, however, is the formulation that the relationship ought to take in the battle against terrorism.

\subsection{The Controversial Divide}

Though some writers have identified specific human rights as significant casualties in the struggle against terrorism, ${ }^{16}$ it has been argued that the notion of 'equality of esteem, ${ }^{17}$ which goes to the heart of all human rights is under greatest threat as a result of 'judging people not by the fact that they simply are but by where they are from and by which culture or faith it is to which they belong. ${ }^{18}$ The fundamental flaw then springs from the categorization of people into 'good' and 'bad', ${ }^{19}$ as this distinction is seen to be drawn on arbitrary grounds. ${ }^{20}$

The disturbing consequence of such a paradigm is two-fold. Firstly, '[it] creates an "ethical dilemma" 21 [and one that]leads them to see human rights not as a subject concerned with the powerless individual wherever he or she might be....but rather as an idea which finds its clearest expression in the West...In this way "human is taken out of "human rights," 22 the particular is superseded by the general, and the subject becomes one that is more about the values than it is about the people. ${ }^{23}$ Secondly, and arguably the more dangerous of the two consequences is 'the suppression of the criminal model based on justice and due process by a security model that is based on fear and suspicion. ${ }^{24}$

\subsection{Mutually Exclusive Objectives?}

Another stream of thought with regards to this relationship is the argument that citizens must be willing to surrender some of their human rights so as to attain the larger goal of achieving security for the community at large. ${ }^{25}$ What is to be noted is that even within this paradigm there are to be found several shades of opinion across the spectrum. To state the two extreme positions would be that on the one hand, it is asserted that ironically the apparatus which safeguards the citizen from abuse of state authority is also the same structure that stands in the way of the state in dealing with challenges that confront the security of the nation. ${ }^{26}$ On the

\footnotetext{
${ }^{14}$ Alston, Philip; Goodman, Ryan and Steiner, Henry (ed.) (2007): International Human Rights in Context: Law Politics and Morals, Oxford, Oxford University Press.

${ }^{15}$ Van Krieken, Peter (2002): Terrorism and the International Legal Order, The Hague, TMC Asser press.

${ }^{16}$ Schmid, Alex P. "Terrorism and Human Rights: A Perspective from the United Nations" in Ranstorp et al, op.cit., p 3.

${ }^{17}$ Gearty, op.cit, p. 2.

18 Ibid.

${ }^{19}$ Gearty, op.cit., p. 2, referring to Ignatieff, Michael (2004) :The Lesser Evil, Political Ethnics in an Age of Terror, Princeton, Princeton University Press.

${ }^{20}$ Ibid.

${ }^{21}$ Ibid.

${ }^{22}$ Ibid: "And who is this "they" that fill the category of lesser (because evil) humans?"

${ }^{23} \mathrm{Ibid}$; Schmid, op.cit.,. " "...should [terrorists] be allowed to enjoy human rights [?]. The answer is "yes." That is exactly the difference between a situation of the Rule of Law and a situation where the law is arbitrary. Do they have the same rights as victims? Again the answer is 'yes'...Everybody is equal before the law".

${ }^{24}$ Ibid.

${ }^{25}$ Donahue, Laura "Security and Freedom on the Fulcrum" in Ranstorp op.cit., p 3

${ }^{26}$ Ibid.
} 
other hand, it is in such exceptional situations that the notion of social compact comes into play as a framework governing state behavior. ${ }^{27}$

This school of thought is disputed on two grounds. Firstly, that it is too narrow a paradigm which fails to take account of the broader implications of the particular State's decision on the inter-state dynamic and secondly, that such a strategy is shortsighted and will likely be self-defeating in that '[i]t ignores the long term costs on restriction on freedoms. ${ }^{28}$ Further, the sustainability of such a strategy is seriously doubted since "what might seem to be an expedient route to head off immediate violence generate grievances reaped in the form of stronger support for violence. ${ }^{29}$

\subsection{Mutually Reinforcing Imperatives?}

A more popular viewpoint in the discourse on counter terrorism and human rights is one which advocates a human rights approach to achieving security. ${ }^{30}$ This is an approach which sees the two concepts as mutually reinforcing imperatives. ${ }^{31}$ 'Partly as a result of September $112001 \ldots$ we may be witnessing a "boomerang effect" in which we must focus on both national and human security and yet realize that excessive focus on one aspect of security at the expense or detriment of the other may well cause it to be "boomeranged" by a poor balancing of ends and means in a changing security environment. ${ }^{32}$ This is the viewpoint advocated by the United Nations ${ }^{33}$ and international human rights non-governmental organizations. ${ }^{34}$ This view might be justified on the grounds that to adopt an approach which ignores human rights would be to equate actions of the state to that of the terrorists and in some instances, even lower, which would augur well for the terrorist and be to the detriment of the state as the terrorist would then likely benefit from negative media scrutiny of government action which would in turn result in heightened sympathy for the terrorists grievance. ${ }^{35}$ What needs to be mentioned here is that even under the broad 'umbrella' of this argument that proposes a human rights-compliant counter-terrorism strategy there exist diverse positions. ${ }^{36}$

\footnotetext{
${ }^{27}$ Ibid.

${ }^{28}$ Ibid.

${ }^{29} \mathrm{Ibid}$; see further in the article for an analysis based on the 'utility calculus' and rights based theory and how they fail to support the argument for sacrificing human rights.

30 Donahue, op.cit., p.7; Gearty, Conor: "Rethinking civil liberties in a counter terrorism world", Field Day Review (2007), at http://www.conorgearty.co.uk/pdfs/FieldDayReview.pdf; "Counter Terrorism versus Human Rights: The Key to Compatibility”, International Federation for Human Rights, Analysis Report (October 2005), at http://www.fidh.org/IMG/pdf/counterterrorism429a.pdf.

31 Ibid.

${ }^{32}$ Liotta, Peter H. "Boomerang Effect: The Convergence of National and Human Security", Security dialogue, vol. 33, no. 4 (2002), pp. 473-488.

${ }^{33}$ See for example K. Annan, Kofi: "Message to the African Union's High Level Inter Governmental Meeting on Terrorism", Algiers (11 September 2002).

${ }^{34}$ Amnesty International: "Human Rights Under Sustained Attack in the "War on Terror", 2 November 2005, available at http://www.amnesty.org/en/report/info/EUR45/050/2005.

${ }^{35}$ Hostettler, Peter "Human Rights and the 'War' Against Terrorism" in Schmitt, Martin and Beruto Gian L. (eds) (2003): Terrorism and International Law: Challenges and Responses International Institute of Humanitarian Law, San Remo, International Institute of Humanitarian Law.

${ }^{36}$ Wilson, Richard A. (2005): "Human Rights in the 'War on Terror", Cambridge, Cambridge University Press; also see for varying standpoints Freeman, Michael: "Order, Rights and Threats: Terrorism and Global Justice in Wilson Ibid.; Hicks, Neil: "The Impact of Counter Terror on the Promotion and Protection of Human Rights: A Global Perspective" in Wilson, Ibid.
} 
This approach might be challenged on several counts. Firstly, it grants human rights a 'higher' status and hence tends to consider the security dimension with scant attention. ${ }^{37}$

Secondly, if fails to appreciate the inherent tensions that persist between the objectives of the two concepts. ${ }^{38}$ Thirdly, it assumes that human rights are indispensable in the fight for security. ${ }^{39}$ Further, such an approach encapsulates an oversimplification of the nature of the relationship between human rights and counter terrorism and evades accounting for the complexities that lie within it. ${ }^{40}$

\subsection{A Nuanced Approach}

While some writers agree on the central point that ' $[\mathrm{t}]$ here is simply no basis for balancing between the two considerations ${ }^{41}$ and that ' $\left.\mathrm{h}\right]$ uman rights must always be observed in the fight against terrorism, ${ }^{42}$ others distinguish this from the prospect of securing a balance "within" the human rights system - and under the monitoring of the established human rights bodies... ${ }^{43}$ For instance, writers like Virginia Held argue that '[w] here rights conflict, we may order them by priorities or stringency; this however is not a matter of maximizing, but of seeking consistency. Some rights may be deemed to have priority over others, or to be more basic than others, but our aim is not to engage in trade-offs. We seek rather to arrive at a consistent scheme in which all the rights of all persons can be respected and none need be violated. $^{, 44}$

The arguments for 'balancing' also veil a significant fallacy in that it frames the relationship between human rights and counter-terrorism as a stand-off, a mere pitting of two notions against each other which is a pedestrian and unsophisticated reflection of the true situation. $^{45}$

Another problematic aspect of the relationship between counter-terrorism and human rights is the issue of whether human rights abuses of terrorists classify as individual actions or whether they should be categorized as group behavior. ${ }^{4645}$

\footnotetext{
${ }^{37}$ Duner in Ranstorp et al., op.cit., p. 3; for opposing views, see Vedel Kessing, Peter: "Terrorism and Human Rights" in Lagoutte, Stephanie et al. (2007): Human Rights in Turmoil: Facing Threats, Consolidating Achievements, Leiden; Boston, Martinus Nijhoff Publishers: "There is a doubt as to whether the fight against terrorism in general might supersede human rights concerns"; Taylor Jr., Stuart: "Rights, Liberties, and Security: Recalibrating the Balance After September 11", in Gus Martin (ed.) (2004): The New Era of Terrorism: Selected Readings, Thousand Oaks, CA ., Sage Publications .

${ }^{38}$ Duner, op.cit., p. 3.

${ }^{39}$ Ibid.

${ }^{40}$ Ibid.: 'He eloquently opines, 'If human rights and democracy are important protective devices then of course we would expect that relatively few democracies would be hit by terrorism....It should be noted that some countries may have seen terrorist deeds on their soil not in spite of being democracies but rather because they were democracies or wanted to perfect their democratic system'; see article further for analysis of 'instrumentality' and 'trade-offs'.

${ }^{41}$ Vedel Kessing, op.cit., p. 9.

${ }^{42}$ Ibid.

${ }^{43}$ Ibid.

${ }^{44}$ Held,Virginia: "Terrorism, Rights and Political Goals", in Primoratz, Igor (ed.) (2005): Terrorism:The Philosophical Issues, Houndmills; Basingstoke; Hampshire; New York, Palgrave MacMillan.

${ }^{45}$ Moeckli, Daniel (2008): Human Rights and Non discrimination in the 'War on Terror, Oxford, Oxford University Press; for opposing view see Luban, David : "Eight Fallacies About Liberty and Security" in Wilson, op.cit., p. 9; For arguments supporting a balancing of interests see Van Krieken, op.cit., p. 5.

${ }^{46}$ See Working paper prepared by Special Rapporteur on terrorism and human rights, Specific Human Rights Issues: New Priorities, In Particular Terrorism and Counter Terrorism, A preliminary framework draft of
} 
"Moreover, a related though separate issue under scrutiny is whether there exists a connection between terrorism and human rights that can be encapsulated within a framework of cause and effect. ${ }^{47}$

\subsection{Final Thoughts}

While the debate surrounding the relationship between counter-terrorism and human rights continues unabated, what becomes necessary then is an analysis of which approach can reap the best results for the people of the world. An examination and analysis of the work of the United Nations human rights treaty monitoring bodies can undoubtedly bring perspective to this issue as the following section will reveal.

\section{The United Nations, Human Rights and Counter-Terrorism - A View from the Human Rights Treaty Monitoring Bodies}

\section{1. 'The Other Side of the Coin'}

A necessary starting point for any discussion on the United Nations' - the human rights treaty bodies included - role in the protection of human rights while countering terrorism is a consideration of States' duty to protect its citizens from acts of terrorism. This then is 'the other side of the coin' in the topic under consideration.

In the case of Delgado Paez v Columbia before the Human Rights Committee (hereafter HRC), the HRC accorded a broad and liberal interpretation to the State's obligation to protect its citizens from acts of terrorism. Referring to Article 9 of the International Covenant on Civil and Political Rights ${ }^{48}$ (hereafter ICCPR), the HRC contended that merely on account of the fact that mention is made of the right of security of person once does not inevitably lead to the conclusion that this "was intended to narrow the concept of the right to security only to situations of formal deprivation of liberty. ${ }^{49}$ Accordingly, in the case of Delgado Paez $\mathrm{v}$ Columbia, the HRC arrived at the decision that deprivation of liberty did not only include arrest or detention but also extends to include threats to life of citizens under its jurisdiction which the State had knowledge thereof. ${ }^{50}$

This decision might be criticized as placing too heavy a burden on the State. However, this might be refuted on the argument that the imposition of the condition of 'knowledge' as necessary to amount to state culpability resonates with a degree of fairness when considering the States' point of view.

This decision may also be challenged from a contrary standpoint. The lack of a blanket state responsibility opens room for arbitrariness and corruption in regressive regimes that are likely to find in-roads to evade such perceptions of knowledge and awareness, the element of

principles and guidelines concerning human rights and terrorism, E/CN.4/Sub.2/2004/47; Van Krieken, op.cit., p. 5.

47 Ibid.; also see discussion/treatment of this issue in C. Bourloyannis-Vrailas, Christiane: "United Nations Human Rights Standards as Framework Conditions for Anti-Terrorist Measures", in Benedek, Wolfgand and Yotopoulos - Marangopoulos, Alice (eds.), (2004): Anti-terrorist measures and human rights, Leiden; Boston, Martinus Nijhoff Publishers.

${ }^{48}$ U.N.Doc.A/6316 (1966) (hereafter ICCPR).

${ }^{49}$ Delgado Paez v Columbia (Case No 195/1985, Views adopted on 12 July 1990).

${ }^{50}$ See Ibid. 
perception being crucial to this qualification. Thus the effectiveness of such a standpoint depends on the good offices of the State's implementation machinery.

Further, it must be noted that this duty on States does not grant it absolute or unfettered powers in fulfilling its obligation. ${ }^{51}$ It calls on State Parties 'to take reasonable and appropriate measures to protect them. ${ }^{, 52}$ Arguably, as 'reasonably' and 'appropriate' are matters of subjective calculation, a high degree of state integrity, both actual and perceived, becomes necessary if this duty/right is not to be made mockery of. ${ }^{53}$

\subsection{A Question of Legitimacy}

The HRC has time and again reiterated the need for counter-terrorism measures adopted by State Parties to be consistent with human rights standards, norms and principles. These suggestions appear to be made with such emphasis and clarity that they seem to advocate the view that the legitimacy of such measures in fact is conditional upon its adherence to established human rights rules. ${ }^{54}$ In 2002, the HRC declared that 'It (the State Party) should ensure that legitimate action against terrorism does not become a source of violations of the Covenant. ${ }^{55}$

In another statement, it went further to state that 'The State Party is under an obligation to ensure that measures taken to implement Security Council Resolution 1373 (2001) are in full conformity with the Covenant. 56

It appears then that such adherence to human rights law by States when effecting counter-terrorism measures is not a mere option for States or a recommendation even, rather it is an 'obligation" ${ }^{57}$ which States "must ensure."

\subsection{The ‘Amoebic’ Nature of Human Rights Law}

International human rights law is not rigid, ${ }^{59}$ either in scope or in application. This 'flexibility' ${ }^{60}$ and 'responsive' ${ }^{61}$ characteristic augurs well for human rights proponents as this, in theory at least, takes human rights law one step closer to effectiveness. In practice, however, this argument is less sustainable. Nevertheless, it does not weaken the argument that human rights are adaptable to situations of grave crises, inter alia, states of emergency which

\footnotetext{
${ }^{51}$ The digest of jurisprudence of the United Nations and Regional Organizations on the Protection of Human Rights while Countering Terrorism (2003): Office of the United Nations High Commissioner of Human Rights at www.ohchr.org/Documents/Publications/DigestJurisprudenceen.pdf.

52 Delgado Paez op.cit.

${ }^{53}$ Also see Committee for the Elimination of Discrimination Against Women, A/54/38 para. 78 (1995); For regional endorsements of this duty to protect by states see decision of the European Court of Human Rights 28 March 2000, para. 62 Kilic v Turkey; "Inter-American Court of Human Rights decision" in Neira Algeria case, January 19, 1995 para. 75.

${ }_{54}^{54}$ Digest of jurisprudence op.cit., p 13

${ }^{55} \mathrm{CCPR} / \mathrm{CO} / 76 / \mathrm{EGY}$, para. 16 (2002).

${ }^{56} \mathrm{CCPR} / \mathrm{CO} / 75 / \mathrm{NZL}$, para. 11 (2002).

${ }^{57}$ Ibid.

${ }^{58}$ Ibid.; further see CCPR/CO/77/EST, para. 8 (2003); CC/PR/CO/75/MDA, para. 8 (2002) and CCPR/CO/73/UK para. 6 (2001).

${ }^{59}$ Duffy, Helen (2005): “The 'War on Terror' and the Framework of International Law”, Cambridge; New York, Cambridge University Press; "Interights"; Report of the Eminent Jurists Panel on Terrorism, Counter-terrorism and Human Rights, International Commission of Jurists (2009).

${ }^{60}$ Ibid.

${ }^{61}$ Ibid.
} 
may include occasions of terrorism. This reveals the fact that human rights law is dynamic in nature, a 'living' concept which is capable of growth and evolution so as to meet the needs of challenging situations. Care, however, should be taken in ensuring that this malleability does not cause the human rights laws to be 'bent out of shape' and eventually beyond recognition where the very fundamentals are eroded.

General Comment No $29{ }^{62}$ of the HRC engages the issue of states of emergency in detail. Though 'suspension' of rights in such states of emergency is provided for, it is far from providing a 'blank check' for State action or inaction. There are certain rights which are catalogues as non-derogable in any situation and other rights when derogable are subject to specific and stringent conditions, both substantive and procedural. ${ }^{63}$

These requirements include that of necessity: 'only when the life and existence of the nation is threatened;' ${ }^{64}$ must be reasonably time-bound given the particular situation at hand: in numerous instances the HRC has denounced the indefinite prolonging of a state of emergency and its attendant derogation of rights for extended periods of time, calling for the 'reviewing [of] the need to maintain the state of emergency. ${ }^{65}$

While it is clear from these statements that the UN human rights treaty monitoring bodies have sought to erect high thresholds of qualification, the lack of clear and specific guidelines on situations which will qualify as a 'state of emergency' has resulted in a near mockery of the system of derogation. ${ }^{66}$ In defense of the UN human rights treaty system, it might be argued that it is not possible to foresee and hypothesize every likely set of circumstances that qualify for such derogation and thus it has done what it could best do in the circumstances, namely, outline general guidelines to be applied appropriately to a variety of situations that is characteristic of the diverse membership of the UN. Hence, it might be argued that anything more than a guiding framework for consideration is neither feasible nor advisable, both theoretically and practically.

Nevertheless, what might help to go some distance in minimizing such abuse is for the $\mathrm{UN}$, through the HRC perhaps, to 'preview' cases, that is, adjudicate before such a decision is implemented by the State, that might qualify as a 'state of

emergency' rather than merely limiting itself to a retrospective ${ }^{67}$ function in this regard. The latter becomes meaningless as the State has already made a decision and considerable damage is done to the human rights of its citizens.

This proposal might be challenged as being a bold suggestion given the deference to the principle of state sovereignty that is accorded near-sacred status by most, if not all, states. A 'middle ground' however would be to set up a 'hybrid' structure comprising both state agents and UN personnel which will help to give neutrality and credibility to decisions on state

\footnotetext{
${ }^{62}$ CCPR/C/21/Rev.1/Add.11.

${ }^{63}$ United Nations General Comment no. 29 on States of Emergency (article 4), CCPR/C/21/Rev.1/Add.11; CCPR/C/79/Add. 78 para. 10 (1997); CCPR/C/79/Add.109 para. 12(1999);

Steiner et al., op.cit., p. 3; Burchill, Richard: "International Human Rights Law: Struggling between Apology and Utopia" in Bullard, Alice (ed.) (2008) : Human Rights in Crisis, Aldershot, England; Burlington, VT, Ashgate.

${ }^{64}$ CCPR/C/79/Add. 76, para. 25 (1997).

${ }^{65}$ CCPR/CO/76/EGY, para. 6 (2002); Also see CCPR/CO/71/SYR, para. 6 (2001) and CCPR/C/79/Add.93, para. 11 (1998).

${ }^{66}$ Duner, op.cit., p 5

${ }^{67}$ P. Vedel Kessing, op.cit., p 9
} 
emergencies, on the one hand, while not disregarding the notion of sovereignty, on the other. The political, administrative and financial contingencies and ramifications involved in such a project, however, needs to be seriously considered, albeit a topic for a separate discussion and not within the reach of the present article.

Thirdly, the requirement for precision in measures regulating states of emergency and the accompanying duty of notification has been emphasized by the HRC. In Comments, Concluding Observations and cases before it, the HRC condemns the broad emergency powers that are in excess of Article 4 of the ICCPR and calls for conformity with it. ${ }^{68}$

The need for justification and for specifics have been stressed by the HRC in cases such as Landinelli Silva v Uruguay and Salgar de Montegro v Columbia. ${ }^{69}$ In the latter case the HRC held that '...the State Party concerned is on duty bound, when it invokes article 4(1) of the Covenant in proceedings under the Optional Protocol, to give a sufficiently detailed account of the relevant facts to show that a situation of the kind described in article 4(1) of the Covenant exists in the country concerned. ${ }^{70}$

The need to respect the non-derogable rights as laid out in article 4 of the Covenant has been emphasized time and again by the HRC. For instance in 2000, 'The State party should take measures to bring its Law on Public Emergency into compliance with article 4 of the Covenant. ${ }^{71}$ Further, the HRC has declared that no leeway may be given on the purported justification that such measures are "temporary decrees ${ }^{, 72}$ or merely because they are 'provisional' 7372 in nature.

Moreover, what is discernible from the view of the HRC is that the legitimacy for State action against terrorism is not derived from the Constitution or legislation of that State which itself might be morally or ethically bankrupt, namely, by not being in congruence with international human rights law and standards, but rather from the principles enshrined within the international human rights law system. ${ }^{74}$ Hence, 'formal legitimacy' can be distinguished from a 'spirit of legitimacy.' This view may be challenged on the basis that it unduly accords supremacy to the international regime and thus encroaches on the doctrine of state sovereignty. This concern may be diluted by the argument that what should remain sovereign in any event is the 'higher moral view' or notion of justice. ${ }^{75}$ In such a situation, the provision of the human rights of the international legal regime, the ICCPR included, will prove to be the easy winner.

The other aspect that the HRC flags is the role that should be played by the judiciary in effecting consistency with article 4 of the Covenant: 'Constitutional and legal provisions

\footnotetext{
${ }^{68}$ For examples see CCPR/C/79/Add. 42. para. 9 (1995); CCPR/CO/72/GTM, para. 11 (2001) and CCPR/C/79/Add. 78 para. 10 (1997).

${ }^{69}$ See cases such as Landinelli Silva v Uruguay [1978] 34, Views adopted on April 81981 and Salgar de Montegro v Columbia [1979] 64, Views adopted on 24 March 1985, para. 10.3.

${ }^{70}$ Salgar de Montegro v Columbia [1979] 64, Views adopted on 24 March 1985, para. 10.3.

${ }^{71}$ CCPR/CO/69/KGZ, para. 12 (2000).

${ }^{72}$ CCPR/C/79/Add. 100, para. 7 (1997).

${ }^{73}$ Ibid.

${ }^{74}$ For this line of thinking see for example Allan, Trevor R. S.: "Constitutional Dialogue and the justification of Judicial Review", Oxford Journal of Legal Studies, vol., 23, no.4 (2003), p.563.

${ }^{75}$ Allan, Trevor R.S., "Human Rights and Judicial Review: A critique of 'due deference", Cambridge Law Journal, vol. 65, no. 3 (2006), p. 671: 'A legal culture of justification demands the supremacy of reason and reason is persuasive argument closely tailored to a situation at hand'.
} 
should ensure that compliance with article 4 of the Covenant can be monitored by the courts. $^{, 76}$

What this seems to suggest then is that the HRC recognizes the potential contribution in judicial review of State action. ${ }^{77}$ Thus, the judiciary is seen as a 'check' on arbitrary behaviour of regressive regimes. ${ }^{78}$ However, it needs to be mentioned that in States with corrupt judiciaries, such judicial intervention can prove to be counterproductive in that the corrupt judiciary can put a 'stamp of approval' on corrupt measures implemented by the State concerned and thereby hurl the effectiveness of article 4 into desuetude.

\subsection{The Right to Life $^{79}$}

A first glance, the human right to life appears to be absolute. However, on closer and further reading it appears to suggest a 'softer' position. Article 6 paragraph 1 of the ICCPR ${ }^{80}$ reads that 'no one shall be arbitrarily deprived of his life.' However, paragraph 2 appears to accord some flexibility to countries which have not established the death penalty stating that 'sentence of death may be imposed only for the most serious crimes...' Article 4 paragraph 2 states that 'no derogation from article 6 may be made under this provison." ${ }^{81}$ However, a State might attempt to seek an in-road by bringing an 'emergency situation' under the pretext of 'not being arbitrary'. Hence this is a significant gap in the text of article 6 which could be open to abuse by States who attempt to masquerade a situation as a state of emergency in order to prove that the action complained of is not arbitrary within the meaning of Article 6 of the ICCPR. ${ }^{82}$

Thus, it would serve the human rights regime well if the wording of Article 6 is made explicit in order to prevent a state of emergency being used by an accused State to justify a violation of the right to life on account of not being arbitrary.

The jurisprudence of the HRC elucidates the fact that the right to life is construed liberally and accorded a broad interpretation to even include situations 'where the use of weapons by combatants has led to the loss of life and deprivation of freedom of large numbers of persons, regardless of the fact that the state of emergency has not been formally declared. ${ }^{83}$ It is striking that even such situations which bear out actions of substantial magnitude and consequences has led to the HRC arriving at the conclusion that such grave circumstances do not justify derogation from this right.

\footnotetext{
${ }^{76}$ CCPR/C/79/Add. 76 para. 38 (1997); Also see CCPR/C/79/Add. 56 para. 13 (1995); Niemi, Heli and Scheinin, Martin (2002): Reform of the United Nations Human Rights Treaty Body System Seen from the Developing Country Perspective, Institute for Human Rights, Abo Akademi University.

77 Ibid.

${ }^{78}$ Ibid; For this line of thinking see for example Choper, Jesse H. (1980): Judicial Review and the National Political Process: A Functional Reconsideration of the role of the Supreme Court, Chicago, University of Chicago Press; Scott, Craig and Mackem, Patrick: "Constitutional Ropes of Sand or Justiciable Guarantees? Social Rights in a New South African Constitution”, University of Pennsylvania Law Review, vol. 141, no. 1 (1992).

${ }^{79}$ Article 6 International Covenant on Civil and Political Rights (ICCPR), U.N.Doc.A/6316 (1966): 'Every human being has the inherent right to life. This right shall be protected by law. No one shall be arbitrarily deprived of his life.'

${ }^{80}$ [U.N.Doc.A/6316 (1966)].

${ }^{81}$ [U.N.Doc.A/6316 (1966)].

${ }^{82}$ [U.N.Doc.A/6316 (1966)].

${ }^{83}$ CCPR/C/79/Add. 54 para. 27(1995).
} 
Such a finding carries merit to the extent that it upholds the value of human life and the right of every human being to claim such a right. Thus, at a theoretical level, the argument appears impeccable. However, descending to the realm of practical reality, and arguably the level that eventually counts, a question which arises is how one may justify such a stance especially in light of a juxtaposition against a situation where the very value that is being argued for seems to lend legitimacy to the violation of that very value and that too, on a larger scale.

What is clear then from the HRC's position is that it is seeking to adopt a 'corrective' rather than a 'retributive' approach when dealing with such cases. ${ }^{84}$ It is shocking if not disturbing that even in situations where among the persons killed include children, the HRC is satisfied with merely 'urge(ing) [the State party] to enforce rigorously the strict limitations on the operational rules as to the use of firearms and the use of rubber bullets against unarmed civilians. $^{85}$

It might be argued on behalf of the UN that employing such conciliatory terms as opposed to the outright condemnation is in keeping with its diplomatic role in international affairs.

However, two matters are worth considering at this point. Firstly, would it not be reasonable and more acceptable even if the UN uses this as its first course of action, it additionally attaches a warning to such a judgment? Thus, it is arguable that the UN should play a stronger role in ratcheting up pressure against States which becomes tantamount to ensuring the effectiveness of such provisions.

The second issue is that in the post 9/11 era where new forms and methods of terrorism are becoming increasingly apparent, are such 'soft' measures advisable? Should not the UN adopt more stringent 'corrective' orders against violating status? ${ }^{86}$

It is noteworthy in the first case that even when there has been no formal declaration of a state of emergency; the HRC was willing to deem that article 4 was applicable.

Furthermore, it must be acknowledged that the treaty monitoring bodies can play a crucial role in 'fleshing out' provisions of the treaties in a meaningful manner by applying the principles and rules contained within the articles in the treaties to actual factual situations on the ground, thereby giving life to the textual expressions of these rights. Such a contribution will not only aid the normative development ${ }^{87}$ of the law but would also serve an additional purpose of being a source of guidance to national jurisdictions ${ }^{88}$ in developing their own jurisprudence when implementing counter-terrorism measures.

\footnotetext{
${ }^{84}$ Dhanapala, op.cit., p. 1.

${ }^{85}$ CCPR/C/79/Add. 93 para. 17 (1998).

${ }^{86}$ See part one for arguments by Taylor in Taylor Jr.: "Rights, Liberties, and Security: Recalibrating the Balance After September 11", in Martin, op. cit.

${ }^{87}$ Mertus, Julie A. (2005): The United Nations and Human Rights: A guide for a new era, Routledge, Global Institutions Series; White, Nigel D. (2002): The United Nations system: towards international justice, Boulder (Colo.), Lynne Rienner Publishers; Mechlem, Kerstin: "Treaty Bodies and the interpretation of human rights", Vanderbilt Journal of Transnational Law, vol. 42, no. 3 (2009).

${ }^{88}$ MacFarlane, Stuart N.:"Charter Values and Response to Terrorism” in Boulden, Jane and Weiss, Thomas G. (2004): Terrorism and the United Nations - Before and After September 11, Bloomington, Indiana Universiry Press.
} 
In the case of Suarez de Guerrero v Columbia, ${ }^{89}$ the HRC concluded that the claimant was arbitrarily deprived of life given the facts of the case, namely the intentional killing of persons by the police during a search operation; lack of warning to casualties; the fact that they were not given a chance to surrender or make an explanation of the reasons for being where they were or doing what they did; lack of necessity and proportionality of police action. To underscore the arbitrariness was the fact that the casualties were only suspects. The chain of causation and burden of proof were both satisfied. Decisions such as this, therefore, can provide useful guidance in giving substance to the right to life in counter-terrorism operations.

Nevertheless, what remains clear from the HRC treatment of the right to life is that the value of this right is to be upheld at all costs in emergency situations. However, there might appear to be extenuating circumstances given the exigencies of the situation which allow for departures, but even when this is possible, it is not easy to establish and satisfy the high thresholds of qualification. Therefore, despite a prima facie reading of the article suggesting the right to be non-derogable, the above discussion has illustrated how this is not a reflection of the true situation. The narrow approach taken by the HRC in limiting the availability of this in-road is commendable in that is safeguards and upholds the importance of this right to a human being, given that it goes to the very core of his/her existence and being, and arguably upon which all other rights rest. ${ }^{90}$

\subsection{The Right to Freedom from Torture and Cruel, Inhuman or Degrading Treatment}

The right to freedom from torture and cruel, inhuman or degrading treatment is absolute and non-derogable as laid down in article 7 of ICCPR: 'No one shall be subjected to torture or to cruel, inhuman or degrading treatment or punishment. ${ }^{91}$

This non-derogable aspect has been reinforced by the HRC in General Comment No.20 on article 7 which specifically states that 'the text of Article 7 allows for no limitation. ${ }^{, 92}$ The HRC goes further to elaborate that the situation of a state of emergency or even the defence of being commanded by those of higher rank cannot be used to justify violation of this right. ${ }^{93}$

This provision then places on every state agent executing counter-terrorism measures a personal responsibility and caution against violating this right. The non-availability of the defense of superior orders or invoking a state of' emergency appears to be a protection against regimes, particularly but not exclusively regressive ones, from abusing their powers. It appears that though prima facie this might seem to be a 'negative' right, one calling for restraint on the part of the state, on close reading it seems that it entails a more 'positive' responsibility in that it requires state officials to take measure to prevent abuse of this right.

Moreover, the HRC points out that from a deprivation of the right in Article 7 can flow a violation of numerous other rights: 'The Committee is aware of the difficulties that the State Party faces in its prolonged fight against terrorism, but recalls that no exceptional circumstances whatsoever may be

\footnotetext{
${ }^{89}$ Suarez de Guerrero v Colombia [1979] 45 Views adopted on 31 March 1982 (paras 12.2, 13.1, 13.3).

${ }^{90}$ Gaur, op.cit., p. 3; Gearty, Conor (2008): "Terrorism and Human Rights" in Essays on Human Rights and Terrorism, Comparative Approaches to Civil Liberties in Asia, the EU and North America, London, Cameron May; For opposing view see Vedel Kessing, op.cit., p. 9.

${ }^{91}$ ICCPR, op.cit., p 20.

${ }_{92}$ General Comment No.20, 10/3/1992.

${ }^{93}$ Ibid. at para. 3.
} 
invoked as a justification for torture, and expresses concern at the possible restrictions of human rights which may result from measures taken for that purpose. ${ }^{94}$

While not for a moment relegating the seriousness of the right to life, the above explanation by the HRC is arguably irrelevant and inapplicable to the right to life since a violation of the right results in an end in itself whereas a violation of the right to be free from torture can be executed both as a means to attain an end or to be an end in itself which arguably becomes more dangerous for human rights protection, in theory at least.

From the counter-terrorism perspective, this right becomes particularly relevant in the context of interrogation techniques used by state officials. The HRC has, however, remained firm in its stand that even 'moderate physical pressure" ${ }^{95}$ which might significantly enable the extracting of information be it even for a noble end such as the "protection of life ${ }^{96}$ would constitute 'abuse" ${ }^{97}$ and a 'violation of article 7. ${ }^{98}$ Thus it is clear that the UN HRC is not willing to compromise on serious violations of human rights even if it may undermine the immediate effectiveness of counter-terrorism operation techniques.

This then is remarkable when considered from a human rights perspective, but will likely be frowned upon by those arguing from a security perspective particularly in the new climate of terrorism ensuing post September 11.

Moreover, the HRC has declared that the detaining of persons as "bargaining chips" 99 in order to induce dialogue constitutes an abuse of article 7 (and 6). ${ }^{10099}$ The prohibition of this form of administrative detention, despite the fact of not involving direct physical harm speaks volumes for the HRC's attitude of adopting an expansive interpretation when considering this right. A similar liberal stance in the appreciation of this right is also seen in HRC's approach to extended solitary confinement. While acknowledging the merits of segregating prisoners for reasons of safety or social stability, the HRC points out that 'segregation involves substantial isolation and may be extended over long periods of time, (and thus) the Committee recalls its General Comment No.20 in which it noted that prolonged solitary confinement of a detained or imprisoned person may violate article 7.'101

The Committee against Torture (CAT) has also been very clear on its position on the right to freedom from torture reinforcing the attitude of the HRC. '.... State party to the Convention....is precluded from raising before the Committee exceptional circumstances on justification for and prohibited by article 1 of the Convention. This is plainly expressed in article 2 of the Convention. '102

\footnotetext{
${ }_{94} \mathrm{CCPR} / \mathrm{CO} / 76 / \mathrm{EGY}$, para. 4 (2002).

${ }^{95}$ CCPR/C/79/Add.93, paras 19, 21 (1998).

96 Ibid.

${ }^{97}$ Ibid.

${ }^{98}$ Ibid.

${ }^{99}$ Ibid.

${ }^{100}$ Ibid.

${ }^{101}$ CCPR/C/79/Add.93, para. 20 (1998).

102 A/52/44, para. 258 (1997); A/51/44, paras. 180222 (1997) Inquiry under Article 20;
}

Also see A/51/44, paras. 180-222 (1997) Inquiry under article 20: 'Under article 2, paragraph 2, of the Convention (Torture Convention), no exceptional circumstances whatsoever, whether a state of war or a threat of war, internal political instability or any other public emergency, may be invoked as a justification for torture.' 


\subsection{Detention}

The issue of detention and its conditions has been raised and addressed in connection with the right to freedom from torture and the right to respect for the inherent dignity of the human person. ${ }^{103}$ Given the fact, however, that it has gained increasing relevance in the counterterrorism era of post 9/11, it warrants special and separate examination and the following discussion seeks to achieve the same. Furthermore, the significant attention and subsequent contribution by the United Nations treaty monitoring bodies in this area calls for special acknowledgement.

The HRC has gone one step beyond the ICCPR in proclaiming that article 10 is a non derogable right. This has been irrespective of the fact that article 4 of the ICCPR which catalogues the non derogable rights has not included article 10 as one of the rights that offers no grounds or scope for limitation.

'In those provisions of the Covenant that are not listed in article 4, paragraph 2, there are elements that in the Committee's opinion cannot be made subject to lawful derogation under article 4: 'Although the right prescribed in article 10 of the Covenant is not separately mentioned in the list of non-derogable rights....., 104

The rationale motivating this position is 'that here the Covenant expresses a norm of general international law not subject to derogaton. ${ }^{105}$ The HRC draws such a conclusion by alluding to the preamble and the 'filial' relationship between articles 7 and 10 of the ICCPR.

While it appears reasonable to see a linkage since both rights 'feed on' and 'feed off' each other, it remains unclear how the HRC could elevate this right to a 'norm of general international law' and thereby distinguish it from other rights. Admittedly, while it is possible for the substance of an article to be the subject of a norm and a right concurrently, it is perhaps advisable, on the arguments for certainty and clarity at least, that it is specifically and explicitly mentioned in the Covenant as such to avoid a situation whereby every right would be accorded the status of a norm of international law and hence non-derogable. This is, however, not to argue against such a proposition, the merits or demerits of which are a subject of a separate discussion, but merely to signal how it becomes problematic in the face of States learning of such a stance only after having effected measures derogating from such rights and without prior knowledge. Hence, for the sake of certainty and clarity, explicit provision is recommended. ${ }^{106}$

Alternatively, to maintain simplicity in the matter would be to operate on the basis that detention in the context of counter-terrorism measures at least is likely in most cases to fall within the ambit of article 7. The decision in Polay Campos V Peru ${ }^{107}$ is a case in point. 'In the Committee's opinion this total isolation of Mr. Polay Campos for a period of a year and restrictions placed on correspondence between him and his family constitute inhuman treatment within the meaning of article 7 and inconsistent with the standards of human treatment required under article 10, paragraph 1, of the Covenant. ${ }^{108}$ Further, the Committee made the following ruling regarding the condition of the claimant's detention: '....his

\footnotetext{
${ }^{103}$ ICCPR, op.cit., p 20.

${ }^{104}$ General Comment No.29, CCPR/C21/Rev. 1/Add.11, para. 13 (2001).

105 General Comment No.29, CCPR/C/21/Rev. 1/Add.11, para. 13(2001).

${ }^{106}$ Duner, op.cit., p. 3.

${ }_{107}^{10}$ Polay Campos v Peru Case [1994] 577, Views adopted on 6 November 1997 (paras. 8.4, 8.6 and 8.7).

${ }^{108}$ Ibid.
} 
violation for 23 hours a day in a small cell and the fact that he cannot have more than 10 minutes sunlight a day, constitute treatment contrary to article 7 and article 10, paragraph 1 , of the Covenant. 109

Thus, what emerges from an examination of such cases is the HRC's inclination to adopt a broad interpretation of non-derogable rights. Further, this is reflective of a general tendency of the United Nations human rights treaty monitoring bodies to place on the state the onus of protecting its citizens to the extent required to preserve the inherent dignity of each of their person. Therefore, the view of the HRC seems to be one that reflects the position that article 7 provides the "meaning" ${ }^{110}$ and article 10 establishes the "standards" implementation.

\subsection{Other Relevant Forms of Detention: Pre-trial and Administrative Detention}

Pre-trial and administrative detentions are relevant to the discussion on counter-terrorism and human rights. ${ }^{112111}$ The UN treaty bodies have laid down important principles to govern such issues and their implications for human rights arising in the context of states' counterterrorism measures.

Elaborate guidelines and specific prescriptions for when a state uses these measures is described by the HRC in General Comment No. 8 on article 9 of the Covenant: 'If so-called preventive detention is used, for reasons of public security, it....must not be arbitrary, and must be based on grounds and procedures established by law (para 1), information of the reasons must be given (para.2) and court control of the detention must be available (para. 4) as well as compensation in the case of a breach (para. 5). And if, in addition, criminal charges are brought in such cases, the full protection of articles 9(2) and (3), as well as article 14, must also be granted.'113

An emerging framework that seems to be crystallizing is one that is not subject to strict procedural requirements and a limited construction of rights enshrined under the various articles in the ICCPR. ${ }^{114}$ What the HRC and other treaty bodies seem to be moving towards is expounding the rights in such a manner that they embrace the core values and principles enshrined within and underpinning all the rights in the ICCPR. ${ }^{115}$ An example of this is the following. "Safeguards related to derogation, as embodied in article 4 of the Covenant, are based on the principles of legality and the rule of law inherent in the Covenant as a whole. ${ }^{116}$ Accordingly, the HRC has stated that article 9 of the ICCPR should be safeguarded as a non-derogable right. ${ }^{117}$

Once again, this ruling is despite the fact that it is not included in the list of non-derogable rights contained in article 4 of the ICCPR : 'The Committee is of the opinion that the principles of legality and the rule of law require that the fundamental requirements of fair trial must be respected during a state of emergency. ${ }^{, 118}$ Following from this logically, the HRC affirmed that '[i]n order to protect non-derogable rights, the right to take proceedings before a court to decide

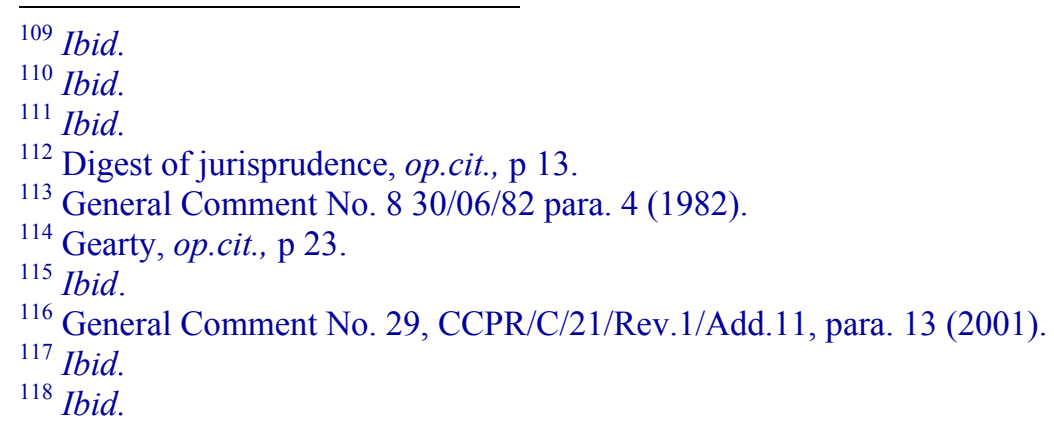


without delay on the lawfulness of detention, must not be diminished by a State party's decisions to derogate from the Covenant. 119

This right was found to be violated in the case of Fals Borda $v$ Columbia ${ }^{120}$ where though the claimants were released following a ruling of the court. 'they had not....had a possibility themselves to take proceedings before a court in order that court might decide without delay on the lawfulness of their decision. ${ }^{121}$ This is an indication of the HRC's interest to protect the right and despite the same result being reached the HRC was not satisfied. What mattered then was that the right should have been made available to the claimants. The outcome was not relevant to the court's ruling.

Certain elements of article 9 have been held to be non-derogable where for instance 'the Committee considers that this reservation [to article 9 of the Covenant] does not exclude, inter alia, the obligation to comply with the requirement to inform promptly the person concerned of the reasons for his or her arrest.'122

The HRC in 2000 echoed the position that 'the application of the Act raises problems of compatibility with articles 9 and 14, para $3(\mathrm{~g})$ of the Covenant, ${ }^{123}$ where the HRC noted that the Act provides for 'periods of detention without charge under the Act (in question) have been increased, that person may be arrested on suspicion of being about to commit an offence, and that majority of persons are never charged with an offence. ${ }^{124123}$

Another aspect of pre-trial detention that has been addressed is the time frame for it to remain in effect. The Committee on the Rights of the Child (CRC) in 2002 expressed 'concern that the Organization Act 7/2000 on terrorism increases the period of police custody...for children accused of terrorism. ${ }^{125}$ The HRC in 1996 called on the State concerned 'to reduce the duration of pre-trial detention and to stop using duration of the applicable penalty as a criterion for determining the maximum duration of pretrial detention., 126125

This can be cited as yet another instance where no specific guidelines or criteria are proposed. Nevertheless, this approach might be welcomed as one which respects the sovereignty of the state concerned to make its own decisions. Moreover, it might be construed as being suggestive of the role that treaty bodies wish to carve out for itself, namely, that of highlighting and flagging areas of concern in States' behavior in counter-terrorism measures and then reverting back to the State to decide on remedial action, thereby informing the state of the need for reform but leaving it to the States' to decide on the particular remedial measures to be taken in such a situation. ${ }^{127}$

Yet another aspect of pre-trial detention that has been discouraged by the HRC is the practice of incommunicado pre-trial detention. In 2002 ' $[\mathrm{t}]$ he Committee...notes that nationals suspected or convicted of terrorism abroad and expelled...have not benefited in

\footnotetext{
119 Ibid.

${ }^{120}$ Fals Borda v Columbia [1979] 46, Views adopted on 27 July 1982 (para.12.3).

${ }^{121}$ Ibid.

${ }^{122}$ CCPR/C/79/Add.81, para.24 (1997).

${ }^{123}$ A/55/40, paras. 422-451 (2000).

${ }^{124} \mathrm{Ibid}$.

${ }^{125} \mathrm{CRC} / \mathrm{C} / 15 / \mathrm{Add} .185$, paras 53-54 (2002).

${ }^{126} \mathrm{CCPR} / \mathrm{C} / 79 /$ Add.61, paras. 12,18 (1996).

127 This is along the liens of the 'weak-form' review proposed by the likes of Tushnet. See Tushnet, Mark (2007)

: Weak Courts, Strong Rights: Judicial Review and Social Welfare Rights in Comparative Constitutional Law,Princeton University Press.
} 
detention from the safeguards required to ensure that they are not ill-treated, having notably been held incommunicado for periods of over one month (articles 7 and 9 of the Covenant). ${ }^{128}$

It is worth taking a moment to reflect on the fact that treaty monitoring bodies are called 'monitoring bodies' for a reason, perhaps in keeping with their mandated task. Hence, it would be futile to expect them to be responsible for the task of implementation. If they were meant to be responsible for implementation, they might have been labeled 'treaty implementing bodies' instead. However, this is not to say that treaty monitoring bodies are completely excluded from the implementation process. Such would be an oversimplification of its mandated role. Arguably, it is fair to say that monitoring is but one facet of the implementation process as the treaty bodies are responsible for the monitoring of the implementation activities of State parties but are not responsible for any deviant or lack of action by State parties.

Moreover, the role of the treaty monitoring bodies in the normative development of the content of the respective treaty provisions is significant. ${ }^{129128}$ They bring the provisions 'alive'. Hence, they play an effective facilitative role between the textual and technical contents of the treaty provisions and the State parties' application of the same.

\subsection{The Right to a Fair Trial}

The right to a fair trial ${ }^{130}$ has been seen to be one of the most contentious human rights in counter terrorism operations. The HRC has accorded the right to a fair trial the elevated status of being a peremptory norm of international law and hence argues that certain aspects of article 14, despite being absent under the catalogue of non-derogable rights in article 4, are non-derogable in any situation: 'State parties may in no circumstances invoke article 4 of the Covenant as justification for acting in violation of humanitarian law or peremptory norms of international law, for instance by....deviating from fundamental principles of fair trial.... ${ }^{131}$ In General Comment No.29, the HRC has made it clear that the list in article 4 is not exhaustive when it declares that 'the category of peremptory norms extends beyond the list of non-derogable provisions as given in article 4, para 2 '. ${ }^{132}$

What emerges as a pattern then is that despite the fact that derogation is apparently present in the structure and vocabulary of the United Nations human rights treaty system, the treaty bodies are reluctant to make allowances for such derogations and hence making them a rarity, as opposed to being a given. It does so by erecting 'clogs' by way of high thresholds reflecting the hesitant approach in allowing human rights to be abandoned. Accordingly, it is fair to conclude that the treaty bodies play a useful role in curtailing and limiting the abuse of these rights and thereby contribute to building the resilience of human rights by minimizing their vulnerability to exploitation in the hands of regressive regimes and hence playing a crucial role in sustaining the 'resilience of the human rights norm.' 133132

The HRC goes on to justify its decision by arguing that 'as certain elements of the right to fair trial are explicitly guaranteed under international humanitarian law during armed conflict, the Committee finds no justification for derogation from these guarantees during other emergency

\footnotetext{
${ }^{128} \mathrm{CCPR} / \mathrm{CO} / 76 / \mathrm{EGY}$, para. 16 (2002).

${ }^{129}$ Mertus, op.cit., p. 20; White, op.cit., p. 20; Mechlem, op.cit., p. 20.

${ }^{130}$ Article 14 ICCPR (see note 79 above).

${ }^{131}$ General Comment No.29, CCPR/C/21/Rev. 1/Add/11 paras. 11, 16 (2001).

132 Ibid.

${ }^{133}$ Rosemary Foot raises this question, see Foot, op.cit., p. 2.
} 
situations... [and that] the principles of legality and rule of law require that fundamental requirements of fair trial be respected during a state of emergency. ${ }^{134}$

Several aspects of the right to fair trial have been explicitly acknowledged Among others is the presumption of innocence which is a requirement in accordance with the rule of law and principles of legality: 'Only a court of law may try and convict a person for a criminal offence. The presumption of innocence must be respected.' 135

A more controversial aspect of the right to fair trial has been the intervention of military and special courts in hearing cases related to terrorism. The HRC calls for the prohibition of 'the trial of civilians by military tribunals in any circumstances. ${ }^{136}$ In this regard, the HRC expresses concern on several counts.

Firstly, the fact that such military and special courts are given too broad a mandate: "It [military courts] is not confined [to trying] criminal cases involving members of the armed forces but also covers civil and criminal cases where, in the opinion of the executive the exceptional circumstance of a particular case do not allow the operation of the courts of general jurisdiction....and [the Committee] is concerned that these courts have jurisdiction to deal with civil and criminal cases involving non-military persons, in contravention of articles 14 and 26 of the Covenant. 137

Secondly, the HRC notes the lack of legal training and capability by such courts to try cases involving human rights violations in particular: 'the Committee recommends that the jurisdiction of the military courts with respect to human rights violations be transferred to civilian courts and that investigations of such cases be carried out by the Office of the Attorney General and the Public Prosecutor'. ${ }^{138}$

Thirdly, it notes the structural deficiency of the court structure with no system for appeals procedures and thus questions the credibility of the judgments meted out: 'The Committee notes with alarm that military courts and state security courts have jurisdiction to try civilians accused of terrorism although there are no guarantees of those courts' independence and their decisions are not subject to appeal before a higher court [article 14 of the Covenant]. ${ }^{, 139}$ In 2002, the Committee against Torture expressed similar concerns on the need for an appeals system in cases of terrorism: 'The Committee recommends that the State party...ensure that all persons convicted by decisions of military courts in terrorism cases shall have the rights to their conviction and sentence being reviewed by a higher tribunal according to law. ${ }^{140}$ Fourthly, the HRC points to the lack of adequate mechanisms for redress where the HRC contends that 'the Committee considers that the pardon does not provide full redress to the victims of trials conducted without regard for due process of the law [and proposes]...the need to establish an effective mechanism, at the initiative of the State, to revise all the convictions handed down by the military tribunal in treason and terror cases....'. ${ }^{141}$ Fifthly, the HRC disapproves the 'system of trial by "faceless judges," in which the defendants do not know who are the judges trying them, denied public trials and which

\footnotetext{
${ }^{134}$ General Comment No.29, CCPR/C/21/Rev.1/Add.11 (2001)

${ }^{135}$ Ibid; Also see General Comment No.13, E/C.12/1999/10.

${ }^{136}$ CCPR/C/79/Add.79, para. 20 (1997).

${ }^{137} \mathrm{CCPR} / \mathrm{CO} / 71 / \mathrm{UZB}$, para. 15 (2001); CCPR/C/79/Add.78, para. 14 (1997).

138 CCPR/C/79Add. 76, para. 34 (1997); CCPR/C/79/Add. 67, para.350 (1996); CCPR/C/79/Add.78. para.14/(1997).

${ }_{139} \mathrm{CCPR} / \mathrm{CO} / 76 / \mathrm{EGY}$, para. 16 (2002).

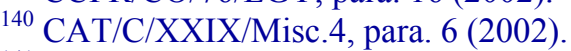

${ }^{141}$ CCPR/C/79/Add.72, para. 10 (1996).
} 
places serious impediments, in law and in fact, to the possibility for defendants to prepare their defense and communicate with their lawyers. ${ }^{142}$

Finally, the HRC has explained why the rationale for a fair trial is defeated by the concept of a 'faceless system of adjudication' in cases such as Polay Campos v Peru ${ }^{143}$ and Gutierrez v Peru. ${ }^{144}$

In the former case, the HRC explained that 'this system fails to guarantee a cardinal aspect of a fair trial within the meaning of article 14 of the Covenant: that the tribunal must be, and be seen to be, independent and impartial. In a system of trial by "faceless judges," neither the independence nor the impartiality of the judges is guaranteed, since the tribunal is ad hoc, may comprise serving members of the armed forces. In the Committee's opinion such a system also fails to safeguard the presumption of innocence, which is guaranteed by article 14, paragraph 2. ${ }^{145}$ These cases are then illustrative of an added role emerging for the treaty bodies. By comparing and applying principles it aids the development of principles of human rights law by applying them to new situations and new phenomenon and is testimony once again to its responsive nature. ${ }^{146}$ In this way, the treaty bodies can make a meaningful contribution by being receptive to and conscious of how new challenges and threats to the international human rights regime might be thwarted or dealt with.

\subsection{Freedom from Discrimination}

In 2002, the HRC declared that 'while it understands the security requirements relating to the events of 11 September 2001, and takes note of the appeal of [the State concerned] for respect for human rights within the framework of the international campaign against terrorism, the Committee expresses its concern regarding the effect of this campaign on the situation of human rights [in the State concerned], in particular for persons of foreign extraction..., ${ }^{147}$

This reveals the UN's position on discrimination in the context of terrorism. The HRC prohibits 'any discrimination and guarantee[s] to all persons equal and effective protection against discrimination on any ground such as race, colour, sex, language, religion, political or other opinion, national or social origin, property, birth or other status. ${ }^{148}$

Given the fact that this rights has been featured repeatedly post 9/11 due to its violation, the UN Committee on the Elimination of Racial Discrimination (UNCERD) has specifically engaged with the issue of racial discrimination in the context of counter-terrorism activities. In a statement made in 2003, the UNCERD '....draws the State party's attention to its statement of 8 March 2002 in which the Committee underlines the obligation of States to "ensure that measures taken in the struggle against terrorism do not discriminate in purpose or effect on grounds of race, colour, descent, or national or ethnic origin." "149

\footnotetext{
${ }^{142}$ CCPR/C/79/Add.67, para. 350 (1996).

143 Polay Campos v Peru [1994] 577, Views adopted on 6 November 1997 (para.8.8).

${ }^{144}$ Gutierrez v Peru [1996] 678, Views adopted on 26 March 2002.

145 Polay Campos v Peru [1994] 577, Views adopted on 6 November 1997 (para. 8.8).

${ }^{146}$ Duffy, op.cit., p. 15.

${ }^{147}$ CCPR/CO/74/SWE, para. 12 (2002).

${ }^{148}$ ICCPR, op.cit., p. 20.

$149 \mathrm{~A} / 57 / 18$, para. 514, Statement on racial discrimination and measures to combat terrorism, para. 5 of the Statement; CERD/C/62/CO/7, para. 24 (2003).
} 
The HRC has explicitly acknowledged the vulnerability of Muslims and Arabs ${ }^{150}$ to discrimination in the wake of post 9/11 terrorist attacks. It has unreservedly expressed the need for protection of individuals 'in particular Arabs and Muslims, from stereotypes associating them with terrorism, extremism and fanaticism.' ${ }^{151}$

Hence, the treaty bodies can play a useful role in drawing international attention to new trends and phenomena which affect human rights protection and promotion.

The HRC is seen to be relatively proactive in this domain. The treaty bodies have responded to the urgency of the situation. The HRC is seen to be urging specific action. For example, 'The State party is....requested to undertake an education campaign through the media to protect persons of foreign extraction.... ${ }^{, 52}$

The language employed by the UNCERD is also reflective of the seriousness of this violation and the negative consequences it holds for human rights. For example, "The Committee recommends that the State party monitor this situation carefully, take decisive action to protect the rights of victims and deal with perpetrators, and report on this matter in its next periodic report. ${ }^{153}$ This then is an illustration of the treaty bodies exercising an authoritative function, one which the UN in general, and the UN treaty monitoring bodies in particular will be well advised to use more often so as to do justice to the inherent potential it possesses to ensure the protection and promotion of human rights in its struggle against terrorism.

Having the benefit of knowledge and experience of dealing with various countries and similar situations, the treaty monitoring bodies can bring in rich advice to aid states' in their efforts to counter terrorism while safeguarding human rights. ${ }^{154}$ The following are illustrative of this. '....the Committee requests the State party to ensure that application of the Anti-terrorism Act does not lead to negative consequences for ethnic and religious groups, migrants, asylum seekers and refugees, in particular as a result of racial profiling. ${ }^{155}$ A better example is seen in a case involving asylum seekers: 'while it (the Committee) notes that this practice by the...Immigration Service was successfully challenged in the High Court and the practice of detaining asylum seekers has been suspended except for a small number of cases, it also notes that the High Court's decision has been appealed by the Immigration Service and that the practice may resume if the appeal is successful. ${ }^{156}$

\subsection{Final Thoughts}

In this part of the article, a clear role for the human rights treaty monitoring bodies is seen to emerge in more than one respect. However, it must be remembered that the treaty monitoring bodies, not unlike the larger United Nations human rights system and indeed the United Nations in general is fraught with significant challenges which need to be addressed to the extent that they have an impact on the role that the human rights treaty monitoring bodies may

\footnotetext{
${ }^{150}$ ICJ Report, op.cit., p. 15.

${ }^{151} \mathrm{CCPR} / \mathrm{CO} / 74 / \mathrm{SWE}$, para. 12 (2002);
}

Also see CERD/C/60/CO/9, para. 15 (2002) and A/57/18, para. 338 (2002): 'The Committee notes with concern that in the aftermath of the events of 11 September 2001, Muslims and Arabs have suffered from increased racial hatred, violence and discrimination.'

${ }^{152} \mathrm{CCPR} / \mathrm{CO} / 74 / \mathrm{SWE}$, para. 12 (2002).

${ }^{153} \mathrm{CERD} / \mathrm{C} / 60 / \mathrm{CO} / 5$, para. 121 (2002).

${ }^{154}$ Niemi et al., op.cit., p. 19.

$155 \mathrm{~A} / 57 / 18 /$ para. 338 (2002).

${ }^{156} \mathrm{~A} / 57 / 18 /$ para. 427 (2002). 
play in protecting human rights while countering terrorism. Such a discussion will be the focus of the following section.

\section{Challenges and Wavs Forward}

\subsection{Biases - Warranted or not?}

Experience shows that the human rights movement has paid extensive emphasis on abuses perpetrated in American and Western regimes by so-called 'Islamic extremists' or 'Jihadists' and has failed to give equal, if not adequate, attention to human rights abuses in 'less open societies' such as Iraq and Afghanistan that hav resulted as a result of invasion and control by certain Western nations. ${ }^{157}$ The United Nations could play a crucial role in rectifying this inequilibrium by becoming 'a strong, independent and authoritative new human rights presence [which] would be the single most effective way of putting pressure on human rights-abusing regimes across the world. ${ }^{158}$

To extend the argument is to contend that in order to secure an increased chance of safeguarding human rights in situations of counter-terrorism is to call for change in the current perception of the human rights movement from one which is seen as being biased against the exercise of a States' executive authority only. ${ }^{159}$ It would be prudent for the human rights movement to chart a more strategic course by projecting an image of genuine concern for the threat to human rights per se, irrespective of who the perpetrators might be, as opposed to being perceived as being only preoccupied with government conduct in such situations. ${ }^{160}$ Regaining the confidence of the organs of state and the larger populace would contribute significantly to achieving the greater goal of fostering support for the protection of human rights principles in executing counter-terrorism measures. ${ }^{16}$

\subsection{A Change of Heart}

Having said this, a related, albeit separate, concern must be acknowledged. A prevailing challenge to the human rights regime is the trend that human rights laws and principles are being flouted not by regressive regimes only but by liberal democracies who previously were among the most vocal in subscribing to and advocating the upholding of the human rights norm in the most trying of circumstances. ${ }^{162}$

What might be somewhat valuable in addressing such concerns is the adoption of ' $a$ much clearer intellectual strategy ${ }^{163}$ and 'engaged scholarship' 164 by the human rights movement. While the former calls for a '...proper understanding of the historical origins of the term, and should also express a clear view as to what civil liberties does (and, more to the point, does not) encompass, ${ }^{165}$ the latter calls for an abandonment of 'detachment" ${ }^{166}$ and

\footnotetext{
${ }^{157}$ Gearty, op.cit., p. 2.

158 Ibid.

${ }^{159}$ Ibid.

${ }^{160}$ Ibid.

161 Ibid.

${ }^{162}$ ICJ Report, op.cit., p. 15.

${ }^{163}$ Gearty, Reflections on Civil Liberties in an Age of Counter-Terrorism in Essays on Human Rights and Terrorism in Gearty, op.cit., p. 23.

${ }^{164}$ Ibid., Idem.

${ }^{165}$ Ibid., Idem.
} 
'neutral[ity]....[in] assess[ing] critically the impact on his or her subject of the anti-terrorism law that he or she is scrutinizing. 167

Here then is a potential intervention point for the United Nations human rights treaty monitoring bodies to play a valuable role. Through the interpretation of human rights and development of a normative framework for specific human rights through its General Comments, Concluding Observations and case decisions, the treaty monitoring bodies can 'contribute to advancing knowledge of human rights ${ }^{168}$ which has been described by some as qualifying as 'research outputs.' 169

\subsection{The Slippery Slope}

Another challenge that remains for the protection of human rights in the counter-terrorist era is the availability of derogations, which poses in the long-term the likely 'risk of norm termination. ${ }^{170}$ The treaty monitoring bodies yet again can play a part in mitigating this risk. If the treaty bodies continue to adopt the attitude which doesn't seek 'to justify violations by reference to this narrow exception or that technical derogation.... ${ }^{171}$ and instead, opt for a principle base framework where 'a set of values that transcend the particular case reflect the strength of a civilization rather than a way of treating human kind.' 172 a more meaningful appreciation of the flexibility of the international human rights regime is upheld and a mockery of the system can be averted. ${ }^{173}$

This view finds positive reinforcement in the 2009 Report of the Eminent Jurists Panel on Terrorism, Counter-Terrorism and Human Rights, Assessing Damage, Urging Action, where the Panel recommends that 'States should take explicit precautions to ensure that any measures, intended to be exceptional, do not become a normal part of the legislative framework. ${ }^{, 174}$ The treaty monitoring bodies then continue to play a crucial role in this regard by keeping states 'on their toes' and 'in check' by reinforcing the language of human rights protection through all its work. Furthermore, the availability of a framework for interpretation ${ }^{175}$ can prove to be a useful tool when the treaty bodies carry out its adjudicative and other functions.

\subsection{The Neglected Rights}

Another worrying phenomenon has been the negligible interest shown in the upholding of economic, social and cultural rights (ESCR) in the counter-terrorism context when compared with that accorded to civil and political rights. ${ }^{176}$ What is surprising of this tendency is its prevalence despite little disagreement on the existence of a connection between counterterrorism measures and its bearing on ESCR: '...it is clear that terrorism and measures

\footnotetext{
${ }^{166}$ Ibid., Idem.

${ }^{167}$ Ibid.

${ }^{168}$ Mechlem, op.cit., p. 24.

${ }^{169}$ Ibid.

${ }^{170}$ Krasno, op.cit., p. 2.

${ }^{171}$ Gearty. op.cit., p. 23.

172 Ibid.

${ }^{173}$ See discussion of examples in Part 2.

${ }^{174}$ ICJ report 2009, op.cit., p. 15.

${ }^{175}$ For human rights framework in giving effect to counter terrorism measures, see Ramcharan, Bertrand (2005): A United Nations High Commissioner in Defence of Human Rights, Leiden; Boston, Martinus Nijhoff Publishers.

176 "Human Rights, Terrorism and Counter Terrorism", Fact Sheet No.32, Office of the United Nations High Commissioner of Human Rights at http://www/ohehr.org/EN/PublicationsResources/Pages/ FactSheets.aspx.
} 
adopted by States to combat it are both influenced by and have an impact on the enjoyment of economic, social and cultural rights of affected individuals...., ${ }^{177}$ To deconstruct the multidimensional nature of this relationship into two of its major characteristics is to, on the one hand, acknowledge the necessity of fulfilling ESCRs in order to thwart the occurrence of circumstances of inter alia, deprivation and inequality, which become an active breeding ground for the beginning or continuation of terrorism ${ }^{178}$ and on the other hand, the restriction or absolute deprivation of benefiting from such rights hampered by particular counterterrorism measures. ${ }^{179}$

Moreover, as civil and political rights and ESCR are considered 'indivisible, interdependent and interrelated, ${ }^{180}$ any comprehensive strategy designed to uphold human rights must necessarily include the integration of ESCR into such a strategy. ${ }^{181}$ There can be said to be some optimism in that there is beginning to appear a slow emergence of interest in this area as is reflected by, among others, the recent United Nations Counter-Terrorism Implementation Task Force Working Group on 'Protecting Human Rights While Countering Terrorism', Expert Seminar on 'The impact of terrorism and counter-terrorism measures on the enjoyment of economic, social and cultural rights (ESCR)', held in November 2008 which focused solely on the issue of counter-terrorism and ESCRs coupled with increasing scholarly interest ${ }^{182}$ in this area. This then is a positive sign. However, a great deal remains to be done and this interest needs to be nurtured, sustained and built on.

The UN treaty monitoring bodies can play an important role in contributing to reverse the current situation by generating interest and awareness through contributing to redefining the terms of the debate on counter-terrorism in such a way so as to include ESCRs. ${ }^{183}$ It can then move on to more stringent measures for fostering greater acceptance of these norms in the human rights agenda in the context of counter-terrorism. At the above mentioned seminar, '[i]n the fourth panel, participants noted that human rights treaty bodies, in particular the Committee on the Elimination of Racial Discrimination, the Committee on the Elimination of Discrimination Against Women and the Human Rights Committee, are well placed to monitor the implementation by States of counter-terrorism measures and their international human rights law including the ICESCR. Participants highlighted that the CESCR has looked at the impact of counter terrorism measures ${ }^{184}$ as well as terrorism on ESCR. ${ }^{185}$

Further, the Task Force proposed '[i]n line with recommendations made by the Special Rapporteur on HR/CT-A/HRC/6/17 para. 74 (b)...that CESCR and other treaty bodies whose mandate include ESCR should develop a systematic practice of addressing counter-terrorism measures by States while monitoring implementation of respective treaties. More generally,

\footnotetext{
${ }^{177}$ Ibid.

${ }^{178}$ Ibid.; United Nations Counter - Terrorism Implementation Task Force Working Group 'Protecting Human Rights While countering Terrorism', Expert Seminar on 'The impact of terrorism and Counter-Terrorism measures on the enjoyment of economic, social and cultural rights' (ESCR) (2008), 5-7 Geneva at

http://www.un.org/terrorism/pdfs/wg_protecting_human_rights.pdf.

${ }^{179}$ Ibid.

${ }^{180}$ Whelan, Daniel J.: "Untangling the Indivisibility, Interdependency, and Interrelatedness of Human Rights", The Human Rights Institute, University of Connecticut 2008, Economic Rights Working Paper Series.

${ }^{181}$ Fact Sheet No.32, op.cit.

182 Flynn, James: "Counter Terrorism and Human Rights: the view from the United Nations", European Human Rights Law Review, vol. 10, no. 1 (2005).

${ }^{183}$ United Nations Counter-Terrorism Implementation Task Force Working Group Expert Seminar, op.cit., p. 44.

${ }^{184}$ CESCR, E/C. 12/1/Add.105, para. 14.

${ }^{185}$ CESCR, E/C, 12/1/Add. 71, para. 8; United Nations Counter-Terrorism Implementation Task Force Working Group Expert Seminar, op.cit., p 44.
} 
human rights-based ESCR monitoring should be strengthened.' 186 Thus a clear role for the UN treaty monitoring bodies has been carved out in the realization of ESCRs in the counterterrorism context and is testimony to the potential that the treaty monitoring bodies carry in ratcheting up the movement for the inclusion of ESCRs into counter-terrorism strategies. It would be able through its norm-setting, recommendatory, and monitoring roles to create and sustain a robust programme for the mainstreaming of ESCRs into the counter-terrorism discourse.

\subsection{A Crippling Dependence}

Another considerable force that the United Nations machinery, human rights treaty bodies included, continue to reckon with is the dependence on the cooperation of Member States to ensure the success of its tasks: "Although, international organizations provide important linkages and standard-bearers throughout the world system, the principle centers of power remain with states....[hence] the role of the United Nations in checking/reversing these abuses remain severely limited and largely dependent upon the political will of the Member States. ${ }^{187}$

Hence, this dependent variable which goes to the core of the human rights treaty monitoring bodies' activities should be kept in mind as one of the continuing and significant challenges facing the United Nations system. It has been argued that this phenomenon has been further compounded in the post 9/11 era. 'The record shows a degree of shift away from liberal and cosmopolitan element of United Nations agenda and values and back toward a statist, power-based and security-oriented focus in international society. ${ }^{, 188}$

However, all is not lost and there is reason for optimism with the emergent mobilization of voices of civil society and non-governmental organizations in the area of human rights protection which has and will continue to have a chilling effect on the insurmountable obstacle to UN action.... ${ }^{189}$ It is contended that the ' $[\mathrm{t}]$ raditional limitation based on Article 2(7) [of the United Nations Charter] are receding. As a result, the margin of action by United Nations has expanded. ${ }^{190}$

\subsection{The Competition Begins}

At an institutional level, a considerable challenge to the continued relevance and popularity of the human rights treaty monitoring bodies is the 'evolution of United Nations treaty monitoring bodies' "competitor" bodies, such as regional human rights bodies; but also interstate and transnational legal systems with inherent human rights competencies, such as the ICJ.... ${ }^{191}$ An important reason why victims of human rights abuses will find the prospect of petitioning at, for instance, the European Court of Human Rights more attractive is that unlike the decisions of cases before the United Nations treaty bodies which lack legal 'teeth', the

\footnotetext{
${ }^{186}$ United Nations Counter-Terrorism Implementation Task Force Working Group Expert Seminar, op.cit., p44; Also see Flynn, op.cit., p. 45.

${ }^{187}$ Joyner, op.cit., p. 5.

${ }^{188}$ MacFarlane, op.cit., p. 45.

${ }_{189}^{189}$ Marks, op.cit., p. 45.

190 Ibid.

${ }^{191}$ Expert Workshop on Reform of United Nations Human Rights Treaty Monitoring Bodies, Senate Chamber, University of Nottingham, 11-12 February 2006, Report, University of Nottingham Human Rights Law Centre.
} 
European Court of Human Rights' decisions 'constitute an enforceable title., ${ }^{192}$ However, some experts do not see the non-enforceability of the United Nations treaty monitoring body decisions as a significant drawback. ${ }^{193}$

\subsection{The Weak Link}

A related challenge, albeit worthy of separate consideration, is the lack of adequate follow-up measures of treaty monitoring bodies' General Comments, Concluding Observations and case decisions. ${ }^{194}$ It is imperative that greater creativity, sustained initiative and focused attention be brought to bear on devising a framework structure for ensuring the follow-up of the work of treaty monitoring bodies both nationally and internationally and with the cooperation of all stakeholders, inter alia, States concerned, the donor community, media, civil society, international, regional and national non- governmental organizations, and National and transnational judicial structures. ${ }^{195}$ This remains crucial to the overall success of the work and role of the treaty monitoring bodies, both actual and perceived. These may include, but not be restricted to, steps to foster greater involvement of a considerably isolated local nongovernmental organization network that has been the result of cumbersome technical requirements; greater involvement in state reporting by key national stakeholders who should submit accurate and verifiable information; avoidance of generalities and ambiguity by treaty monitoring bodies when formulating General Comments, Concluding Observations and case reports; and ratcheting up confidence in the treaty body complaints procedure nationally to restore credibility in a system that has thus for been disrepute for its inefficiency and slow pace. $^{196}$

\subsection{The Diplomatic Faux Pas}

A considerable challenge that has plagued the functioning of treaty monitoring bodies since its inception is that in an attempt to secure universal ratification, the treaty system has compromised on standards and with the availability of a system of reservations and derogations has thus created for itself the dangerous situation where 'norms risk dilution., ${ }^{197}$

\subsection{Svstemic Challenges}

The sluggishness in meeting reporting deadlines and at times complete negligence even to submit a report by State Parties has oft been recorded as a major challenge in the treaty body system. ${ }^{198}$

Further, in situations where States actually do in fact execute their reporting obligations, it has become apparent that on many an occasion they fail to realize the larger goal of inducing and stimulating change at the national level, be it policy, legislation or judicial attitudes. 199

\footnotetext{
192 Schmidt, Markus : "Follow-up Mechanisms Before United Nations Human Rights Treaty Bodies and the United Nations Mechanisms Beyond" in Bayefsky, Anne F. (2000): The UN Human Rights Treaty System in the 21 - Century, Kluwer Law International.

${ }^{193}$ Nowak, Manfred "The United Nations High Commissioner for Human Rights: a link Between Decisions of Expert Monitoring Bodies and Enforcement by Political Bodies" in A.F. Bayefsky (Ibid).

${ }^{194}$ Niemi et al., op.cit., p. 19.

${ }^{195}$ Ibid.

${ }^{196}$ Expert Workshop on Reform, University of Nottingham, op.cit., p 48.

${ }^{197}$ Marks, op.cit., p. 45.

${ }^{198}$ Ibid.

${ }^{199}$ Ibid.
} 
Proposals for reform ${ }^{200}$ have included suggestions for the fusion of committees to form a 'mega-committee which would examine all reports. ${ }^{201}$ such a proposition, however, is a solution as much as it is a problem. Admittedly, while improving efficiency, preventing conflicting jurisprudence and duplication of work outputs of the treaty monitoring bodies on the one hand, ${ }^{202}$ it rids the system of one of its greatest strength, the possibility of rendering concentrated expertise as has been meted out by each specialized body under the stratified regime of treaty monitoring bodies. ${ }^{203}$

A persistent quandary confronting the treaty body system is that while they are encouraged to become more outspoken and effective in their supervisory roles...they must ask States whose action they condemn, to streamline the treaty system and make it stronger and more effective by giving them wider legal powers and more resources. ${ }^{204}$ Hence, what can help to overcome this challenge is the mobilization of States' support to pursue this much needed reformation of the treaty monitoring body structure. ${ }^{205}$ It is in a situation such as this, perhaps, that the international human rights non-governmental organizations can play a crucial part through the collaboration efforts of its networks.

\subsection{State Sovereignty}

The ability of the United Nations Treaty Monitoring Bodies to adequately address national counter-terrorism measures is impeded by the fact that they apply only to practices of States that have ratified the treaties. This is problematic in that a number of treaties that address rights that are often implicated by counter-terrorism measures have not been ratified by a significant number of States. As a result, ability of the treaty monitoring bodies to play a meanignful role in the upholding of human rights in the face of counter-terrorism measures is compromised.

Despite the fact that some of the treaties entertain individual petitions if a State has acceded to the relevant procedure, it has not reached frutition in that only a small number of states have acceded to the complaint procedures. In any event, the complaints regarding counterterrorism measures received has been observed to be marginal

\subsection{Final Thoughts}

Following from the role that emerged for the UN human rights treaty monitoring bodies in the discussion in part two, the third part of the article expounds a secured role that the treaty monitoring bodies can claim given the significant potential they are seen to carry for the contribution to the larger United Nations' human rights system in upholding human rights in the context of counter-terrorism. Despite the somewhat daunting challenges they face what remains clear is that there has been no indication of a collapse in spirit to defend the noble cause of human rights. If anything, the preceding discussions have made it clear that what

\footnotetext{
${ }^{200}$ Report: Strengthening the United Nations: An agenda for further change, A/57/387 (2002); Report in Larger Freedom: Towards development, security and human rights for all, A/59/2005 (2005).

${ }^{201}$ Marks, op.cit., p. 45; Plan of Action submitted by the United Nations High Commissioner for Human Rights on request by the Secretary-General in his report in Larger Freedom (ibid.) A/59/2005/add.3.

${ }^{202}$ M. Kjaerum: "The UN Reform Process in an Implementation Perspective", quoting Sano, Hans Otto and Scharff Smith, Peter in Lagoutte et al, op.cit., p. 9.

${ }^{203}$ Marks, op.cit., p 45

${ }^{204}$ Evatt, "The Future of the Human Rights Treaty System, Forging Recommendations", in Bayefsky, op.cit., p. 48.

${ }^{205}$ Ibid; Also see T. Buergenthal, "A Court and Two Consolidated Treaty Bodies”, in A.F. Bayefsky, op.cit., p. 48.
} 
seems to have transpired, on the contrary, is renewed vigour and resolve in standing for what they were originally created to champion.

\section{Conclusion}

The road ahead is undoubtedly a long and winding one. While the United Nations human rights treaty monitoring bodies have contributed to the upholding of human rights in the face of a 'new brand' of terrorism and counter-terrorism, ${ }^{206}$ the challenges they face ${ }^{207}$ make their task daunting, now more than ever. ${ }^{208}$ It becomes apparent then that while the human rights monitoring bodies do in fact have part to play, it must be remembered that it is merely but one component in the larger United Nations human rights machinery. Further, the entire United Nations system constituting the work of the human rights, legal and political branches of the system in the area of counter-terrorism by itself is not placed in a self-sufficient position that it may command success purely through its own initiative. The dependence on State parties for the success of its activities will continue to plague all the work of the United Nations ${ }^{209}$ particularly in matters such as counter-terrorism where national state interest and sensitivity is understandably very high. ${ }^{210}$

Having said this, it must be recognized that the United Nations human rights treaty monitoring bodies do and can continue to play a valuable role in sustaining the 'resilience of the human rights norm ${ }^{211}$ in this age of battling against terrorism. Its contribution through normative development towards the understanding of the core and penumbra of human rights principles is among its greatest strengths. ${ }^{212}$ Further, by continually instilling the importance of mainstreaming human rights into the counter-terrorism discourse, ${ }^{213}$ it serves as an everpresent reminder of the relationship between counter-terrorism and human rights ${ }^{214}$ and the futility of sacrificing one in the name of the other. ${ }^{215}$

Moreover, the human rights treaty monitoring bodies carries with it a potential to occupy the niche of playing a leadership role ref $^{216}$ in spearheading the human rights perspective $^{217}$ in the counter-terrorism debate. Accordingly, it can serve a useful complementary role to the work of the international human rights community including academia, human rights non-governmental organizations and practitioners.

\footnotetext{
${ }^{206}$ Digest of Jurisprudence, op.cit., p 13; Flynn, op.cit., p. 45.

${ }^{207}$ See discussion in part 2.

${ }^{208}$ Joyner, op.cit., p. 5.

209 Ibid; MacFarlane, op.cit., p. 45.

${ }^{210}$ Digest of Jurisprudence, op.cit., p. 13: 'No one doubts that States have legitimate and urgent reasons to take all due measures to eliminate terrorism'.

${ }^{211}$ R. Foot raises the question in Foot, op.cit., p. 2.

${ }^{212}$ Mertus, op.cit., p 22; White, op.cit., p 22; Mechlem, op.cit., p. 22.

${ }^{213}$ Marks, op.cit., p 45; 'A new doctrine of human security based on a holistic approach to human rights deserves to capture the imagination of people...the UN is necessarily the principle framework for the development and expansion of this idea'.

${ }^{214}$ Ibid.

215 Annam, op.cit.., p. 8.

216 Pillay, op.cit., p. 25.

${ }^{217}$ Marks , op.cit., p. 45: 'The principal institutional framework for furthering human rights is the United Nations, the only structure with a general mandate for realizing all human rights in all countries.'
} 
While appreciating that the implementation and enforcement aspects of the human rights treaty system have been recognized to be amongst its weakest links, ${ }^{218}$ it might be proposed that the United Nations should not be expected to be a champion of implementation and enforcement activities given the inherent discrepancy of State dependence that exists in realizing the goals of its tasks. ${ }^{219}$ This has and will always remain the prerogative of the Member States. ${ }^{220}$

Instead, the United Nations, human rights treaty monitoring bodies included, could and should see itself as a leader in norm-creation and norm-sustainment. ${ }^{221}$ However, it must be remembered that even sustaining the norm is ultimately dependent on the legal and political will of Member States 222

When discussing the work and role of the United Nations Human Rights Treaty Monitoring Bodies in protecting human rights while countering terrorism, the larger institutional issues which need to be addressed at the international level must not be overlooked. These issues are four-fold. First, what strategies and which institutions (civil or military) ought to be engaged in order to counter terrorism. Second, in countering terrorism are there situations which justify the encroachment of universally accepted human rights and if so, which international institutions ought to be mandated with the task of making such assessments. Third, the need for a harmonization of counter-terrorism strategies, operations and measures at international, regional and national levels. Finally, the methods that ought to be employed in the event there arises a dispute in the matter of human rights violation in counter-terrorism measures. ${ }^{223}$

A consideration of these issues becomes imperative for its inevitable bearing on the role that the United Nations Treaty Monitoring Bodies ought to and might play and is an area which is worthy of further consideration and study, though not in direct purview of the present paper.

It must be remembered that there still remains to be addressed a 'fundamental contradiction at the heart of international law' in that individuals do not possess full legal personality in the international arena as the State has the ultimate decision-making authourity whether to become signatory to the treaty which would grant individuals the rights guaranteed. Moreover, States have the authority to not bind itself to the optional protocol which grants individuals the right to petition individual complaints even if it decides to ratify the treaty. ${ }^{224}$ This will undoubtedly remain an obstacle to the United Nations Human Rights Treaty Monitoring Bodies having a robust presence in the international arena for protecting human rights while countering terrorism.

\footnotetext{
${ }^{218}$ Niemi et al, op.cit., p 19 ; University of Nottingham Treaty Body Reform workshop, op.cit., p. 48.

${ }^{219}$ Marks, op.cit., p. 45; ; Joyner, op.cit., p 5; This is not to say that the treaty monitoring bodies have no role to play in implementation. The argument is that it should not be held responsible for a lack of success given this discrepancy; White, op.cit., p. 22.

${ }^{220}$ Marks, op.cit., p 45; Joyner, op. cit., p. 5; G8 Declaration on Counter Terrorism, From La Maddalena To L'Aquila Summit 2009, at http://www.g8italia2009.it/G8/Home/G8-G8-Layout locale 1199882116809 Atti.htm; "All States must meet their obligations to implement the UN sanctions regime....".

${ }^{221}$ MacFarlane, op.cit., p. 45: 'One of the most important roles of the world organization is to promote certain values and "the terms" of international debates'; He goes on to justify its role [in this regard i.e. creation and sustenance of norms] is particularly important since near universality of membership conveys a degree of legitimacy that is not enjoyed by regional institutions or coalitions of like-minded States.'

${ }^{222}$ Joyner, op.cit., p. 5.

223 von Schorlemer, Sabine: "Human Rights: Substantive and Institutional Implications of the War Against Terrorism", European Journal of International Law, vol. 14, no. 2 (2003), pp. 265-282.

${ }^{224}$ White, Nigel D. (2002): The United Nations System, Toward International Justice, Boulder, Co., Lynne Rienner.
} 
Any reform efforts to improve the effectiveness of the United Nations Human Rights Treaty Monitoring Bodies needs to address the current information and coordination gaps that exist between the treaty monitoring bodies and both national and international actors that are crucial to successful national implementation of the treaty body outputs.

The outputs of the treaty monitoring bodies are plagued with lack of clarity and detail necessary for any direction to be taken by national governments and civil society actors and institutions towards successful implementation. This needs to be rectified to ensure concrete improvements in the human rights practices in national constituencies when counter terrorism. Resource constraints, limited accessibility to civil society, and local non-governmental organizations are caused by the complex and cumbersome procedures associated with the treaty monitoring body system. This ought to be overcome through outreach to currently marginalized groups through well-thought out inclusion strategies and measures. ${ }^{225}$

Ultimately, the crux of the issue lies at the need to improve respect for determinations under the communications procedures of the United Nations Treaty Monitoring Bodies system. The need for such is reflected by the legacy of delayed or incompliance by national institutions and organs of state that has been witnessed and recorded across both developed and developing States alike.

\footnotetext{
${ }^{225}$ Expert Workshop on Reform of United Nations Human Rights Treaty Monitoring Bodies, The University of Nottingham Human Rights Law Centre (11-12 February 2006).
} 